\title{
Phonological Adaptation and Morphosyntactic Integration in Igbo-English Insertional Codeswitching
}

\author{
Ihuọma I. Akinremi \\ University of Jos, Nigeria
}

\begin{abstract}
In African-European language insertional codeswitching, the African language is usually the matrix language that provides the morphosyntactic frame into which elements of the embedded language (a European language) are inserted. Morphosyntactic integration, especially of inserted verbs and verbal expressions, is a defining feature of such codeswitching. The study describes insertional codeswitching in the speech of Igbo-English bilinguals. Igbo, a West-Congo language, is the matrix language, and English, an Indo-European language is the embedded language. It notes that as a result of major phonological differences (segmental and suprasegmental) between Igbo and English, namely, a harmony vs. non-harmony vowel system and a tone vs. stress system, English verbs often lack the requisite phonological features for
\end{abstract}

Ihuọma I. Akinrẹmi

Department of Linguistics and Nigerian Languages

University of Jos, P. M. B. 2084, Jos. Plateau State, Nigeria. 930001

Phone: +234 8162133 064; Email: homaremi@gmail.com

Received August 15, 2015; Revised November 9, 2015; Accepted November 30, 2015 
54 Phonological Adaptation and Morphosyntactic Integration in Igbo-English

morphosyntactic integration into Igbo. The phonological features of English verbs are, therefore, adapted in such a way that English vowel segments fit into the Igbo vowel system, and English word stress fits into the Igbo tonal system. English verbs with phonologically adapted features are thus enabled to achieve full morphosyntactic integration into Igbo and to function like Igbo verbs in terms of selection of inflectional affixes and subject pronouns on the basis of tone and vowel harmony. The study describes Igbo-English insertional codeswitching as a highly rulegoverned linguistic phenomenon.

Keywords: Igbo-English, insertional codeswitching, matrix language, embedded language, integration

\section{Introduction}

Codeswitching is the most common and most studied feature of bilingual speech. In general terms, codeswitching (which is also known as code-mixing, although the two terms are sometimes distinguished) entails a shift, in the course of speaking one language, to another language for a word, phrase, sentence or an utterance (Grosjean 1989: 10). The typology of structural patterns of intrasentential codeswitching across language pairs outlined in Muysken (2000) recognises insertion, alternation and congruent lexicalisation. According to him, these patterns have shaped the models of structural analysis of codeswitching.

Backus (2010), however, notes that the current most widely accepted classification of the structure of codeswitching is into two main types - insertion and alternation. He distinguishes the two patterns as follows: "in insertion, a grammatical frame in one language may host one or more content words from another language, 
while in alternation monolingual chunks in two different languages alternate" (Backus 2010: 229). In other words, in insertional codeswitching there is an asymmetry in the roles of the participating languages, such that a matrix/base language and an embedded language can be distinguished (Muysken 2000, Backus 2010). The matrix language is more grammatically dominant than the embedded language - it sets the morphosyntactic frame for the clause and supplies the system morphemes (functional categories) (MyersScotton 1998, 2002). In alternational codeswitching on the other hand, none of the languages is dominant; the speaker "can best be seen as speaking now one language and now the other" (Bentahila \& Davies 1998: 49). The insertional and alternational patterns are illustrated in Igbo-English ${ }^{1}$ codeswitching in (1) and (2) respectively:

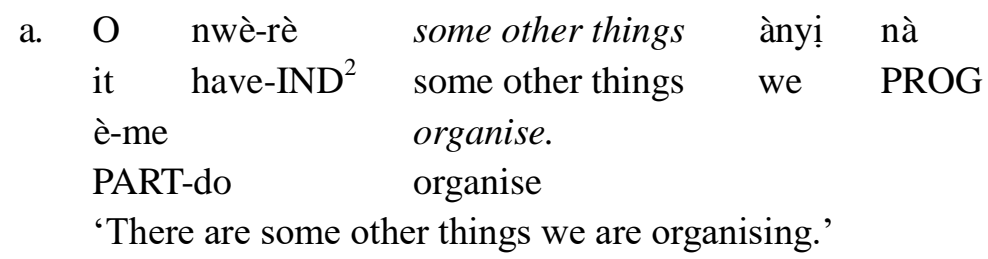

${ }^{1}$ Igbo linguistic material is in normal font while English material is in italics in the bilingual data. Tone is marked on Igbo material as follows: high tone (and its variant, downstep) is unmarked (e.g., $a$ ); low tone is marked with a grave accent (e.g., è).

2 The following abbreviations are used in the interlinear glosses for Igbo-English data: $\mathrm{BNF}=$ benefactive; $\mathrm{EMPH}=$ emphasis marker; $\mathrm{ES}=$ extensional suffix; FUT = future marker; HAB = habitual aspect marker; HRM = harmony vowel; IMPERS. PN. = impersonal pronoun; IND = indicative suffix; INF = infinitive marker; NEG = negative suffix; OVS = open vowel suffix; PART = participle prefix; PAST $=$ past tense suffix; $P E R F=$ perfective aspect marker; $P F X=$ prefix used in certain verb forms with noun (phrase) or plural pronoun subject; PREP = preposition; $\mathrm{PROG}=$ progressive aspect marker; $\mathrm{EV}=$ epithetic vowel; VOC = vocative part of a discontinuous subject pronoun. 
56 Phonological Adaptation and Morphosyntactic Integration in Igbo-English

b. Ò ma-rọ nà the youth of the church

s/he know-NEG that the youth of the church

nà- à-watch-ị ya.

PROG PART-watch-EV him

'S/he did not know that the youth of the church were watching him/her.'

c. Ọ bụ̀ tomorrow kà ànyị gà- è-move.

it be tomorrow that we FUT PART-move

'It is tomorrow that we will move.'

(2) a. I gbànyụ̀-rụ̀ phone gị throughout ...

you switch off-PAST ${ }^{3}$ phone your throughout ...

'You switched off your phone throughout yesterday. Since morning I've been calling you.'

b. O nà- è-je somewhere with her husband. she PROG PART-go somewhere with her husband 'She is going somewhere with her husband.'

c. E-nwè-rè '̀े strong belief that we'll make it. VOC-have-IND I strong belief that we'll make it 'I have a strong belief that we'll make it.'

3 'PAST' is used in this study to refer to a sub-class of Emenanjo's (1978) 'indicative verb form', which is marked by an $r \mathrm{~V}$-suffix. 'PAST' is applied to active verbs, for which a past tense is clearly identifiable, while the term 'indicative' is retained for stative verbs to signify a form which "simply indicates the salient facts about the verb used without regard to time" (Emenanjo 1978: 171). 
Insertional codeswitching, as in (1), may involve lone content words or multi-word constituents of the embedded language (Muysken 2000, Backus 2010). Insertion has been noted as the dominant pattern in codeswitching involving an African language and a European one (Auer 1999, Muysken 2000) and the matrix language in such instances is usually the African language (Kamwangamalu 1989, as cited in Bentahila \& Davies 1998: 30). Studies on such language pairs frequently report the morphosyntactic integration of lexical items of the European language into the African one by means of inflectional affixation; e.g., Bokamba (1989) describes Lingala-French codeswitching in which French verbs show the subject-verb agreement and tense/aspect morphological markings that are characteristic of Lingala verbs; Myers-Scotton (1997) describes Swahili-English data in which English verbs are inflected with Swahili tense/aspect prefixes exactly like Swahili verbs.

Poplack, Sankoff \& Miller (1988) describe integration as adaptation of material of one language into the existing patterns of another language. They identify a number of types of integration morphological (e.g., inflection for gender and number for nouns), syntactic (inflection for tense, mood and person), phonological (change in the phonological shape of items to conform to the patterns of the recipient-language), and social (the diffusion of other-language material in the community of the recipient language).

There are two major positions on the significance of (morphosyntactic) integration in language contact phenomena. Some scholars regard it as evidence of borrowing and the feature that distinguishes codeswitching and borrowing (e.g., Poplack \& Meechan 1998; Poplack, Sankoff \& Miller 1988), whilst others consider it a major feature of insertional codeswitching (Bokamba 1989), especially of verbs (Muysken 2000). 
58 Phonological Adaptation and Morphosyntactic Integration in Igbo-English

In the present study integration is viewed as evidence of an insertional pattern of codeswitching in which Igbo is the matrix language, and English, the embedded language. The study notes that in the Igbo-English language pair, the process of morphosyntactic integration is preceded by phonological integration because the inherent phonological features of inserted English verbs often do not correspond to the features required for their morphosyntactic integration into Igbo via affixation. The phonological integration of inserted English verbs is described in the study as the adaptation of the inherent features of English verbs into the patterns of Igbo, especially in areas of divergence between the phonological systems of the two languages, namely a harmony vs. non-harmony vowel system and a tone vs. stress system.

The rest of the study is structured as follows. Section 2 explores the matrix-embedded language asymmetry in Igbo-English insertional codeswitching and gives evidence for Igbo as the matrix language. Section 3 describes the adaptation of English word stress to fit into the Igbo tonal system, and Section 4 describes the adaptation of the vowel segments of English verbs to fit into the Igbo vowel system. Section 5 concludes the paper. The significance of phonological adaptation as a condition for the full morphosyntactic integration of English verbs is highlighted throughout the study.

\section{The Matrix-Embedded Language Asymmetry}

Eze's (1998) study of lone English verbs in Igbo-English codeswitching notes that with regard to the pattern of occurrence of Igbo affixes, lone English verbs function as if they were Igbo verbs. 
The following are examples (Eze 1998: 187):

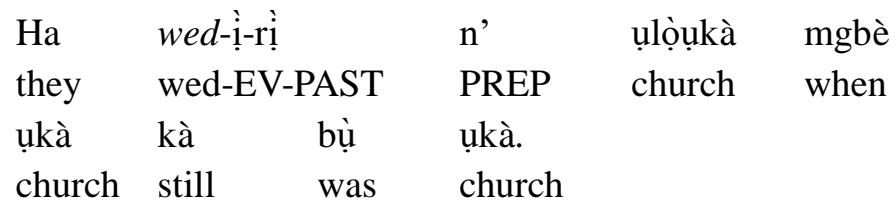

'They wedded in church when the church was still authentic.'

$\begin{array}{ll}\text { (4) Ò̀ } & \text { work-ụ̀-ghị. } \\ \text { it } & \text { work-EV-NEG }\end{array}$

'It did not work.'

The Igbo affixes attached to the lone English verbs (i.e., the past tense suffix on the verb wed in (3) and the negative suffix on the verb work in (4)) are used in the same way they would be used with the equivalent Igbo verbs. The present study notes that the same degree of morphosyntactic integration in (3) and (4) is observable in English verbs inserted into Igbo structure as part of multi-word expressions, as in (5) and (6). It is noted that the morphosyntactic structure in (5) and (6) is framed in Igbo; although the English verbal expressions are inserted clause-peripherally, the inflection on the English verbs is evidence of an Igbo matrix language frame.

$$
\begin{aligned}
& \text { O nwè-rè plan ha set-ị-r-ị ten years ago. } \\
& \text { it have-IND plan they set-EV-PAST ten years ago } \\
& \text { 'There is a plan they set (put in place) ten years ago.' }
\end{aligned}
$$

$\begin{array}{lllll}\text { (6) That amount } & \text { kà } & \text { o } & \text { jì } \\ \text { that } & \text { amount } & \text { EMPH } & \text { he } & \text { take }\end{array}$


60 Phonological Adaptation and Morphosyntactic Integration in Igbo-English

na- à-run the office.

HAB PART-run the office

'It is that amount he runs the office with.'

The English verbs set and run in (5) and (6) respectively, though part of multi-word English expressions, are inflected with Igbo affixes like the lone verbs in (3) and (4).

Following the assumption that verbs generally provide striking examples of integration in insertional codeswitching (Muysken 2000), the above examples illustrate insertional codeswitching involving a matrix-embedded language asymmetry, in which Igbo is the matrix language that sets the morphosyntactic frame. Further evidence of the matrix language status of Igbo is provided by the following examples:

(7) Lecture $\mathrm{m}$ nà- a-terminate between 11 and 12. lectures my HAB PART-terminate between 11 and 12 'My lectures (usually) terminate between 11 and 12.'

(8) Some batteries

à-run-ụ̀-go

down. some batteries PFX-run-EV-PERF down 'Some batteries have run down.'

$\begin{array}{lll}\text { E-weigh-ì-chà-rà } & \text { m } & \begin{array}{l}\text { those options. } \\ \text { those options }\end{array} \\ \text { VOC-weigh-EV-ES-PAST } & \text { I } & \end{array}$

(10) Other private individuals nà- à-struggle other private individuals PROG PART-struggle 
to set up their schools.

to set up their schools

'Other private individuals are struggling to set up their schools.'

In examples (7) through (10), although Igbo does not supply any lexical items, it consistently supplies all the functional elements. This makes Igbo the matrix language, in line with the System Morpheme Principle (Myers-Scotton 1997, 1998, 2002) which requires all syntactically relevant system morphemes to come from the matrix language, while the embedded language may supply the content morphemes.

\section{Adaptation of English Word Stress}

The phonological features of affixes attached to Igbo verbs in monolingual speech often depend on, or are determined by, those of the verb root, particularly with respect to tone and vowel harmony. For example, Igbo morpho-phonological rules require the tone on the participial prefix $(a-/ e-)$ to be dissimilar to the tone of the (initial syllable of the) verb root (Emenanjo 1978). This is illustrated in the following Igbo examples.
a. Chinwè nà-
è-nwe
nsògbu.
Chinwe PROG
PART-have
problems
'Chinwe is having problems.'

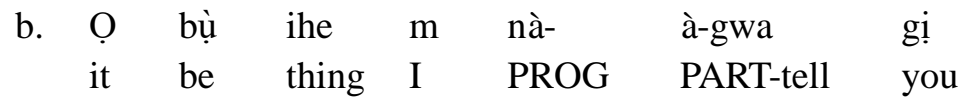


62 Phonological Adaptation and Morphosyntactic Integration in Igbo-English

ogè ahụ̀.

time that

'It is what I was telling you at that time.'

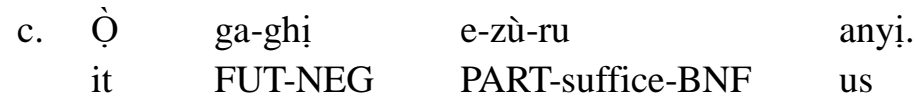

'It will not be sufficient for us.'

The high tone verbs nwe and gwa in (11a) and (11b) select a low tone participial prefix, $\grave{e}$ - and $\grave{a}$ - respectively, on the basis of vowel harmony. Similarly, the low tone verb zù in (11c) selects a high tone prefix $a$-.

However, in Igbo-English insertional codeswitching, English verbs are inserted into the Igbo morphosyntactic structure with their inherent stress feature, and thus lack the tonal feature to select Igbo affixes. The tonal requirement for morphosyntactic integration is met by an adaptation of the word stress feature of the English verb, as described in the following contexts:

(i) When an English verb is inflected with an Igbo infinitival prefix The Igbo infinitival prefix ( $i-/ i-)$ has an inherent high tone. When attached to verbs, a following syllable with a high tone is realised as downstep, while a syllable with a low tone remains low (Emenanjo 1978). The Igbo infinitival prefix is attached to monolingual English verbs in the following examples:
a. i-send
(to send)
b. i-meet
(to meet)
c. i-move
(to move)
d. i-check
(to check)
e. ị-run
(to run) 
In all the examples in (12), the infinitival prefix is pronounced on a high tone, while the monosyllabic English verb is pronounced on a step tone. ${ }^{4}$ This means that the English verb is treated as a high tone monosyllabic verb, i.e., the stress on it counts as a high tone. The adaptation of English primary stress into the Igbo tonal system as a high tone is also observed in the following disyllabic and trisyllabic English verbs:
a. i-'register
(to register)
b. i-'settle down
(to settle down)
a. i-ope'rate
(to operate)
b. i-up'grade
(to upgrade)
c. ị-reco'mmend
(to recommend) (Ahukanna 1990)
d. i-disa'ppoint
(to disappoint)

In the examples in (13) and (14), the primary stress on the English verbs, as recorded in actual speech, is indicated by " before the stressed syllable. In some of the words, the placement of primary stress is different from what obtains in Standard British English. This reflects a general tendency for the primary stress of words in Standard British English to shift to the right in Nigerian English (Omachonu 2008). It was observed that the syllable following the high-toned Igbo infinitival prefix is pronounced on a step tone if it is stressed, as in the examples in (13), but on a low tone if unstressed, as in the examples in (14). This again suggests that English primary stress is adapted into Igbo as a high tone, and the lack of stress as a low tone.

\footnotetext{
4 The voice falls after the downstep tone, as if the verb stem is pronounced with a falling tone.
} 
64 Phonological Adaptation and Morphosyntactic Integration in Igbo-English

(ii) When the English verb is used in participle form after an Igbo auxiliary verb

Verbs occurring after an Igbo auxiliary verb (e.g., nà = progressive; $g \grave{a}=$ future; $n a g h i=$ progressive negative; $g a g h i=$ future negative; gaghi $n a=$ future progressive negative) are required to appear in participle form, marked with the prefix $(a-/ e-)$. This also applies to English-origin verbs in the context of codeswitching (except when the English verb begins with a vowel, as observed in the expressions nà-insist $=$ 'is insisting', nà-announce = 'is announcing'). Igbo morphosyntax requires tonal dissimilation between the participial prefix and the (initial syllable of the) verb root. This also applies to English verb roots in codeswitched speech, as in the following sentences with monosyllabic English verbs.
a. Ò̀ bụ̀ nnà gị

$$
\text { nà- }
$$
à-run system ${ }^{5}$ à?
it be father your PROG PART-run system this 'Is it your father that runs this system?'
b. ... ànyị à-na- è-live in peace.
... we PFX-PROG PART-live in peace
'... we were living in peace.'

In examples (15a) and (15b) the participial prefix is on a low tone, suggesting that the stress on the monosyllabic English verb (run, live) is adapted into Igbo as a high tone. In other words, the stress on the English verb counts as a high tone for the participial prefix to be on a low tone.

\footnotetext{
5 Note the imposition of Igbo word order on the English expression run this system (realised as 'run-system-this'). The matrix language supplies the functional element $\grave{a}$ ('this') and also determines word order.
} 
The following are further examples of monosyllabic English participles recorded in the corpus. Different auxiliary verbs are illustrated in the examples.
a. gà-è-press
(will press)
b. gà-à-pass-ị
(will pass)
a. nà-à-crack
(is cracking)
b. nà-è-pick-i up
(is picking up)
c. nà-à-like
(like(s))
d. nà-à-jot
(is jotting)

a. naghị à-work (is not working)

b. naghị à-browse (is not browsing)

gaghị à-size

(will not size)

gaghị na- è-press (will not be pressing)

The tone of the participial prefix is low in all the examples, no matter the auxiliary verb used, an indication that the stressed syllable of the verb counts as a high tone. It is noted that an epithetic vowel is often added to consonant-final English verbs, as in (16b) and (17b). The requirement for verb roots to end in vowels in Igbo accounts for such epithetic vowels.

When the English participle is disyllabic or trisyllabic, the stressed syllable of the verb also counts as a high tone, as in the following examples. 
(21)
a. nà-à-'battle
(is battling)
b. nà-è-'lecture
(is lecturing)
c. gà-è-'video
(will video-record)

(22)
a. gà-a-su'pport
(will support)
b. nà-e-super'vise
(is supervising)
c. nà-a-com'plain
(is complaining)
d. anarọ e-re'ject
(does not reject)

In (21) and (22), primary stress is marked as recorded in actual speech (with " before the stressed syllable). Tonal dissimilation is observed in the examples. The low tone on the participial prefix when followed by a stressed syllable in the English verb root, as in the examples in (21), indicates that English primary stress is adapted into Igbo as a high tone. The high tone on the participial prefix when the following syllable of the English verb root is unstressed, as in the examples in (22), indicates that an unstressed English syllable counts as a low-tone syllable in Igbo.

(iii) When an English verb is inflected with the Igbo indicative/past tense suffix

The Igbo indicative/past tense suffix $(-r \mathrm{~V})$ consists of the $r$-sound and a vowel identical to the final syllable vowel of the verb root. The suffix has a low tone and affects the tonal pattern of the verb in the following way: "both the verb and the suffix have low tones for simple verbs ... even though the first syllable may not be low for some tone classes (of complex verbs) all subsequent syllables are low tone" (Emenanjo 1978: 169). For many English verbs inflected with the Igbo indicative suffix, an epithetic vowel is observed before the suffix, as in the following monosyllabic verbs: 

a. win-ì-rì
(won)
b. need-ì-rì
$($ need(s))
c. jump-ụ̀-rụ̀
(jumped)

The stressed monosyllabic English verbs in (23) are pronounced as high tone roots, whilst the epithetic vowel and the suffix are pronounced on a low tone, in accordance with Igbo tone rules. The adaptation of English primary stress into Igbo as a high tone is also observable in disyllabic English verbs inflected with the Igbo indicative/past tense $r \mathrm{~V}$-suffix, such as the following:
a. su'ppose-ù-rù
(supposed)
b. disa'ppoint-ị-rị
(disappointed)
c. re'duce-ù-rù
(reduced)

The epithetic vowel and the indicative suffix are realised on a low tone in the above words. Here again, English primary stress (indicated by ") is adapted into Igbo as high tone, whilst lack of stress counts as low tone consistently in all the examples.

\section{Adaptation of English Vowel Segments}

The Igbo vowel system consists of eight vowels that are divided into two harmony sets, as follows:
A: $\mathrm{e}$
o $\quad \mathrm{u}$
B: $\quad$ a
ọ $\quad$ ụ

The harmony groups A and B are characterised variously as Wide 
Set vs. Narrow Set (Emenanjo 1978) or Advanced Tongue Root (ATR) vs. Retracted Tongue Root (RTR) vowels (Ladefoged 1964 \& Stewart 1967 as cited in Emenanjo 1978). The vowel harmony feature of Igbo requires all vowels in simple (non-compound) words to belong to the same group. Igbo verbal prefixes and suffixes generally harmonize with the vowel of the adjacent syllable of the verb root (Emenanjo 1978, Eze 1998).

Eze (1998) reports that lone English verbs in Igbo contexts show the same degree of vowel harmony as Igbo verbs, although he does not include examples, neither does he discuss contexts, in which the vowel of an English verb adjacent to an Igbo affix is not found in the Igbo language. This study notes that in instances in which the vowels of the English verb do not occur in Igbo (e.g., /æ/, / / /, /ə/, /3:/; see Jowitt 2000) morphosyntactic integration is achieved by first adapting the vowel of the English verb closest to the affix into the Igbo vowel system; the verb is then inflected with an Igbo affix on the basis of the [ATR] feature of the adapted vowel. English monophthongs are adapted to fit into the eight-vowel harmony system of Igbo, while diphthongs are treated as combinations of the eight Igbo vowels. ${ }^{6}$ The adaptation of the vowel segments of English verbs on the basis of the restrictions imposed by the harmony feature of the Igbo vowel system is observable in the following contexts:

(i) When an English verb is inflected with an Igbo participial prefix In the following examples, the Igbo participial $a$-/e-prefix is attached to English monosyllabic verbs and the inflected verbs are used with a variety of auxiliary verbs. The vowel of the English verb, as recorded in actual speech, is indicated after each example.

\footnotetext{
${ }^{6}$ While the statement applies to diphthongs such as /ai/, /au/ and /כi/, it does not apply to others; e.g., /ei/ is adapted as [e:] in make.
} 
(25)

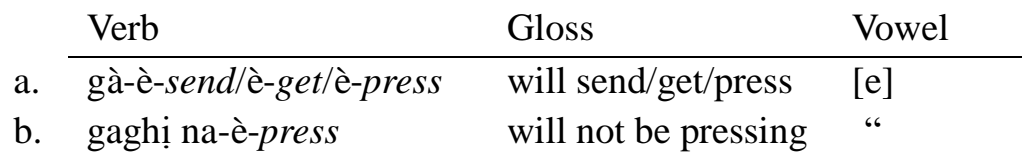
gà-è-need/è-pick/è-lead will need/pick/lead
a. gà-à-pass

b. nà-à-crack

will pass

[a:]

is cracking
a. gà-à-work/à-watch
will work/watch
[ว:]
b. naghị à-work
is not working
a. nà-à-jot-ụ
is jotting
[D]
b. nà-à-run down
is running down

$$
\text { nà-è-show-i }
$$

is showing

[o:]

a. nà-à-try/à-like

b. gaghị à-size

is using

nà-è-build

is building

is trying/likes

[ai]

will not size

Whilst some vowels in the English verbs in the above examples have equivalents in the Igbo vowel system (e.g., /e/ in send, /D/ in jot, /ai/ in like, /u:/ in use and /au/ in browse), others do not, and have been replaced with vowels that occur in Igbo (e.g., /3:/ in work is replaced 
with [ऽ:]), /æ/ in pass and crack is replaced with [a:]), $/ \mathrm{N} /$ in run is replaced with [D] and /ou/ in show is replaced with [o:]). These vowel replacements are similar to those in the speech of Igala users of English as a second language, as reported by Omachonu (2008). He establishes the following replacements of English vowels that do not exist in Igala: $\mathrm{a} \rightarrow \mathrm{a}:, \mathrm{u} \rightarrow \mathrm{u}:, æ \rightarrow \mathrm{a}, \mathrm{i}: \rightarrow \mathrm{i}$, ə $\rightarrow \varepsilon, æ / ə \rightarrow \mathrm{a}$, ə $\rightarrow \mathrm{D}$. An additional feature of Igbo-English bilingual speech is that the vowels of English verbs are replaced with Igbo vowels in order to achieve vowel harmony with Igbo prefixes. This is a form of adaptation which is necessary for the morphosyntactic integration of the English verbs. Vowel adaptation is also observed in the following disyllabic verbs:

\begin{tabular}{lll} 
Verb & Gloss & Vowel \\
\hline gà-a-prepare-ị & will prepare & {$[\mathrm{I}]$}
\end{tabular}
a. nà-à-sponsor
is sponsoring
[D]
b. gà-a-support
will support
“
c. gà-a-continue
will continue
d. nà-à-publish
is publishing

Vowel harmony between the initial vowel of the English verb and the Igbo participial prefix is achieved directly in (35) and (36a) because the initial vowels of the verbs, / $\mathrm{i} /$ and $/ \mathrm{D} /$ respectively, also occur in the Igbo vowel system. In (36b)-(36d), however, the initial vowels, / / / in support and continue, and $/ \Lambda /$ in publish, are adapted into Igbo as $/ \mathrm{D} /$. Vowel harmony is then established with the Igbo prefix.

(ii) When an English verb is inflected with the Igbo infinitival prefix 
The form of the Igbo infinitival prefix $(i-/ i-)$ must harmonise with the (initial) vowel of the inserted English verb. This is achieved straightforwardly if the vowel of the English verb also occurs in Igbo, as in (37):

\begin{tabular}{lllc} 
& Verb & Gloss & Vowel \\
\cline { 2 - 3 } a. & i-send-ì & to send & {$[\mathrm{e}]$} \\
b. & i-register & to register & “ \\
c. & ị-repair & to repair & {$[\mathrm{I}]$}
\end{tabular}

However, if the (initial) vowel of the English verb is not also a vowel of Igbo, the English vowel is adapted into the vowel system of Igbo, as in the following examples:

\begin{tabular}{llll} 
& Verb & Gloss & Vowel \\
\cline { 2 - 3 } a. ị-run down & to run down & {$[\mathrm{D}]$} \\
b. & ị-upgrade & to upgrade & “ \\
c. & ị-continue & to continue & “ \\
d. & ị-work & to work & {$[\mathrm{D}]$} \\
e. & i-graduate & to graduate & {$[\mathrm{a}]$}
\end{tabular}

In the above verbs, the vowels $/ \Lambda /$ (in run and upgrade) and / $/ 2$ (in continue) are adapted into Igbo as [D], /3:/ (in work) is adapted as [0:], and /æ/ (in graduate) as [a], in order to achieve vowel harmony with the Igbo infinitival prefix for morphosyntactic integration.

(iii) When an epithetic vowel is added to an English verb The addition of an epithetic vowel to consonant-final English verbs to meet the requirement of the Igbo language for syllables to end in vowels is an aspect of the phonological adaptation of inserted 
72 Phonological Adaptation and Morphosyntactic Integration in Igbo-English

English verbs. For example the monosyllabic English verbs in (39) and (40) end in consonants, and epithetic vowels have been added to them.
a. work-ụ̀
(work)
b. jump-ụ̀
(jump)

(40)
a. need-ì
(need)
b. reject-ị
(reject)
c. finish-ì
(finish)

However, the corpus for this study also shows epithetic vowels attached to English verbs that end in open syllables, such as prepare and show in the following examples:

... certain reagents ị gà- a-prepare-ị.

... certain reagents you FUT PART-prepare-EV

'... certain reagents you will prepare.'

(42) E

$\begin{array}{lllll}\text { E } & \text { show-ì-rì } & \text { ya } & \text { nà } & \text { television. } \\ \text { IMPERS.PN } & \text { show-EV-PAST } & \text { it } & \text { PREP } & \text { television }\end{array}$

'It was shown on television.'

In all the examples in which an epithetic vowel is added to an English verb, vowel harmony is observed between the epithetic vowel and the final vowel of the English verb or the adapted equivalent of the final vowel.

(iv) When vowel harmony is required between an English verb and an Igbo subject pronoun 
Certain subject pronouns in Igbo (known variously as dependent subject pronouns (Emenanjo 1978), and pronominal clitics (Anyanwu 2012)) have two forms each. The vowel harmony requirement of Igbo is such that "the [ATR] vowel quality of pronominal clitics is conditioned by the [ATR] vowel quality of a following verbal element" (Anyanwu 2012: 380). In insertional codeswitching, this requirement holds, irrespective of the language of origin of the verb. In the following examples, vowel harmony is observed between the (initial) vowel of an English verb and an Igbo subject pronoun $(o / o=$ he, she, it; $i / i=$ you $(\mathrm{sg}$.$) ; ale =$ impersonal pronoun; $a-/ e-=$ the vocative part of the discontinuous form of the first person subject pronoun $a-l e-\ldots m$ 'I').

$$
\begin{aligned}
& \text { a. ... ̣̀ resolve-ọ ị-hapụ } \quad \text { i-register. } \\
& \ldots \mathrm{s} \text { /he resolve-OVS INF-leave INF-register } \\
& \text { '...s s/he resolved not to register.' }
\end{aligned}
$$
b. $\mathrm{O}$ win-ì-rì.
s/he win-EV-PAST

'S/he won.'

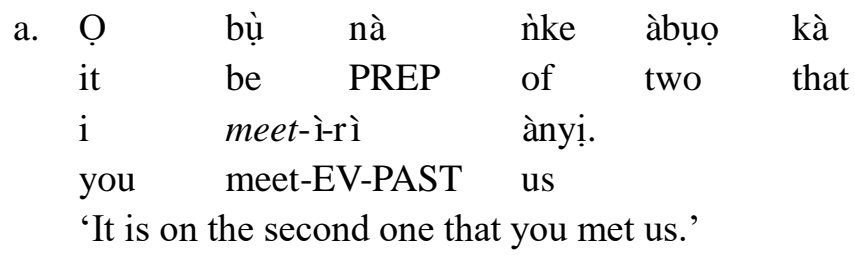
b. I
surprise-ị-rị
m.
you surprise-EV-PAST
me
'You surprised me.' 
74 Phonological Adaptation and Morphosyntactic Integration in Igbo-English
a. E-feel-ì-rì
m
nà ...
VOC-feel-EV-IND
I that ...
'I feel that ...'
$\begin{array}{lll}\text { b. À-support-ụ-rọ̀ } & \mathrm{m} & \begin{array}{l}\text { that idea. } \\ \text { VOC-support-EV-NEG }\end{array} \\ \mathrm{I} & \text { that idea }\end{array}$
'I don't support that idea.'

(46) a. A

condemn-ụ̀-rụ̀

IMPERS.PN ya.

$\operatorname{him} /$ her

'S/he was condemned.'

\begin{tabular}{|c|c|c|}
\hline Before & è & finish-ì-e \\
\hline fore & IMPERS.PN & finish-EV-OVS \\
\hline
\end{tabular}

Vowel harmony between the (initial) vowel of the English verb and the Igbo subject pronoun is straightforward in all the examples, except in (44b) and (45b), in which the initial vowel of the English verbs $(/ \mathrm{\partial} /)$ is adapted as $/ \mathrm{D} /$ for vowel harmony to be achieved with the Igbo subject pronoun.

(v) When the English verb is inflected with certain other Igbo affixes There are other Igbo affixes that require harmony with a vowel of the verb (irrespective of the language of origin of the verb, in the context of insertional codeswitching). Such harmonising affixes include the $a$-le-prefix used to form the bound cognate noun (as in (47)), the verbal prefix $(a-/ e-)$ which occurs when the subject of the sentence is a noun or plural pronoun in certain verb forms (as in (48)), and the open vowel suffix used in verb forms such as the imperative and the 
subjunctive (Emenanjo 1978) (as in (49)).
a. A-jump-ụ̀-rụ̀
m
à-jump-ụ̀.
VOC-jump-EV-PAST I
HRM-jump-EV
'I (actually) jumped.'
b. E
kwèsì-rì i-check-ì
IMPERS.PN suppose-IND INF-check-EV
ya
e-check-ì.
it
HRM-check-EV
'It is supposed to be checked.'

a. Ha a-mind-ị-rò̀.

they PFX-mind-EV-NEG

'They do not mind.'

b. Onye mụ-rụ ya e-play-ị-ghị

person bear-PAST him PFX-play-EV-NEG

his or her role.

his or her role

'His parent (lit. 'the person that bore him') did not play his or her role.'

$\begin{array}{lll}\text { a. Ha make-ì-e } & \text { sure. } \\ \text { they make-EV-OVS } & \text { sure }\end{array}$

'Let them make sure.'

$\begin{array}{lllll}\text { b. Kà } & \text { ànyị } & \text { strike-ị-a } & \text { balance here } \\ \text { let } & \text { us } & \text { strike-EV-OVS } & \text { balance } & \text { here }\end{array}$

'Let us strike a balance here.' 
76 Phonological Adaptation and Morphosyntactic Integration in Igbo-English

$\begin{array}{llll}\text { c. Kà } & \mathrm{m} & \text { send-ì-e } & \text { to Mrs. A. } \\ \text { let } & \text { me } & \text { send-EV-OVS } & \text { to Mrs. A. }\end{array}$

'Let me send to Mrs. A.'

In (47) through (49), the vowel harmony required between the relevant vowels of the English verbs and the Igbo suffixes for morphosyntactic integration to be achieved applies straightforwardly in all the examples, except in (47a) and (49a), where the English vowels $/ \Lambda$ and /ei/ are adapted as [D] and [e:] respectively.

It is noted that certain English vowels are adapted ambiguously into the Igbo vowel system in the context of codeswitching. For example, the English vowel /e/ harmonises with [+ATR] affixes in certain contexts, as in (50), and with [-ATR] affixes in other contexts, as in (51).
a. i-send-ì
(to send)
b. è̀-send-ì
(participle form of 'send')
c. spend-ì-rì
(spent)

(51)
a. condemn-ụ̀-rụ̀ (condemned)
b. wed-ị-rị
(wedded) (Eze 1998)
c. reject-ị-rị
(rejected)

The status of English /e/ in the above examples seems to depend on its quality in an individual's speech, such that if it is realised with the quality of the denser Igbo /e/ it selects [+ATR] suffixes, but if realised with the quality of the less dense English /e/, it selects [ATR] affixes. However, the English vowel /ei/ seems to be adapted consistently into Igbo as [e:] and to select [+ATR] affixes, as seen in the following examples. 

a. i-dictate-ì
(to dictate)
b. make-ì
(make)

Another example of ambiguity in the adaptation of English vowels into the Igbo vowel system is observable with the English vowel /i/, which is sometimes realised as in English (or the equivalent of the Igbo [-ATR] ' $i$ '), as in the word resolve in (43a) above, or as the equivalent of the English /i:/ (or the [+ATR] Igbo ' $i$ '), as in the word win in (43b) above. In all the instances discussed, vowel harmony is regularly observed between the Igbo affixes and the relevant vowels in inserted English verbs. If the vowels of the English verbs also occur in Igbo, the verbs select Igbo affixes straightforwardly; otherwise their vowels are adapted to fit into the Igbo vowel system in order for morphosyntactic integration to be achieved via affixation.

\section{Conclusions}

The study has described the integration of English verbs in insertional codeswitching in which the morphosyntactic structure is framed in Igbo. It noted that the inserted English verbs often lack the requisite phonological features to select Igbo inflectional affixes for morphosyntactic integration to be achieved. The inherent segmental and suprasegmental features of English verbs are therefore adapted to fit into the Igbo phonological system to enable them to select Igbo affixes and function in the Igbo morphosyntactic frame. The stress feature of English verbs is adapted in such a way that primary stress counts as a high tone in the selection of affixes, while the lack of stress on a syllable is interpreted as a low tone. With respect to the vowel harmony requirement of the Igbo morphosyntactic frame, 
78 Phonological Adaptation and Morphosyntactic Integration in Igbo-English

when the relevant vowel in the English verb is also a vowel of Igbo, vowel harmony applies straightforwardly and morphosyntactic integration is achieved. However, if the relevant English vowel does not occur in Igbo, the English vowel is first adapted into the Igbo vowel harmony system before morphosyntactic integration is achieved. The phonological adaptation necessary for the morphosyntactic integration of English verbs, as described in the study, demonstrates that Igbo-English insertional codeswitching is a highly rule-governed linguistic phenomenon.

\section{References}

Ahukanna, J. 1990. Bilingualism and Code-Mixing in Language Use in Nigeria: The Case of Igbo-English Bilinguals. In E. Emenanjo (ed.), Multilingualism, Minority Languages, and Language Policy in Nigeria 175-291. Agbor: Central Books.

Anyanwu, O. 2012. Pronominal Subject Clitics in Igbo. Theory \& Practice in Language Studies 2.2, 377-388.

Auer, P. 1999. From Codeswitching via Language Mixing to Fused Lects: Toward a Dynamic Typology of Bilingual Speech. International Journal of Bilingualism 3.4, 309-332.

Backus, A. 2010. The Role of Codeswitching, Loan Translation, and Interference in the Emergence of an Immigrant Variety of Turkish. Working Papers in Corpus-Based Linguistics \& Language Education 5, 225-241.

Bentahila, A. \& E. Davies. 1998. Codeswitching: An Unequal Partnership? In R. Jacobson (ed.), Codeswitching Worldwide 2549. Berlin: Mouton. 
Bokamba, E. 1989. Are There Syntactic Constraints on CodeMixing? World Englishes 8.3, 277-292.

Emenanjo, E. 1978. Elements of Modern Igbo Grammar: A

Descriptive Approach. Ibadan: Oxford University Press.

Eze, E. 1998. Lending Credence to a Borrowing Analysis: Lone English-Origin Incorporations in Igbo Discourse. International Journal of Bilingualism 2.2, 183-201.

Grosjean, F. 1989. Neurolinguists, Beware! The Bilingual is not Two

Monolinguals in One Person. Brain \& Language 36, 3-15.

Jowitt, D. 2000. Nigerian English Usage: An Introduction. Ikeja: Longman Nigeria.

Muysken, P. 2000. Bilingual Speech: A Typology of Code-Mixing. Cambridge: Cambridge University Press.

Myers-Scotton, C. 1997. Duelling Languages: Grammatical

Structure in Codeswitching. New York: Oxford University Press. . 1998. Structural Uniformities vs. Community Differences

in Codeswitching. In R. Jacobson (ed.), Codeswitching

Worldwide 91-108. Berlin: Mouton.

. 2002. Contact Linguistics: Bilingual Encounters and

Grammatical Outcomes. New York: Oxford University Press.

Omachonu, G. 2008. Comparative Optimality Theory Analysis of

Primary Stress Assignment in Standard British and Nigerian

English. Journal of Language \& Translation (Now Called Journal of Universal Language) 9.1, 91-112.

Poplack, S. \& M. Meechan. 1998. Introduction. How Languages Fit

Together in Codemixing. International Journal of Bilingualism 2.2, 127-138.

Poplack, S., D. Sankoff \& C. Miller. 1988. The Social Correlates and Linguistic Processes of Lexical Borrowing and Assimilation. Linguistics 26, 47-104. 